\title{
Perancangan Program Aplikasi Pemesanan Tiket Sepak Bola Berbasis Desktop Menggunakan Visual Studio 2010
}

\author{
Givy Devira Ramady ${ }^{1}$, Herlina $^{2}$, Silvia Roza ${ }^{3}$ \\ Program Studi Teknik Elektro dan Informatika ${ }^{1,2,3}$ \\ Sekolah Tinggi Teknologi Mandala, Jl.Soekarno-Hatta No. 597 Bandung \\ Email : givy.d.ramady@gmail.com ${ }^{1}$, lina.herlina55@gmail.com², \\ silvi.roza@gmail.com ${ }^{3}$
}

\begin{abstract}
ABSTRAK
Dalam era globalisasi ini informasi sangatlah penting dan juga sangatlah dibutuhkan oleh setiap orang. Karena teknologi informasi telah menjadi sumber kunci utama dan juga sangatlah berperan penting bagi kemajuan bangsa. Salah satunya dalam masalah administrasi dalam penjualan tiket di sebuah tempat usaha. Kondisi saat ini pengolahan tiket di stadion sepak bola ini masih bersifat manual. Maka dari itu kita bisa memanfaatkan sentuhan teknologi dalam bentuk administrasi pada loket pemesanan tiket masuk ke stadion sepak bola serta bisa menyimpan data para pengunjung yang datang. Metode yang digunakan dalam penelitian ini merupakan model waterfall karena merupakan metode pengembangan yang terstruktur dan dalam laporan akhir ini dapat dilakukan secara sistematis dan terarah. Program aplikasi tiket sepak bola berbasis desktop dibuat dengan menggunakan microsoft visual studio 2010 dengan VB NET sebagai bahasa pemrograman aplikasi serta $M y S Q L$ sebagai database digunakan untuk menyimpan dan mengolah data. Dari hasil pengujian, aplikasi yang dibuat dapat bekerja secara optimal tanpa mengalami kendala.
\end{abstract}

Kata Kunci : Aplikasi, Tiket, Visual Studio, $M y S Q L$

\begin{abstract}
In this era of globalization information is very important and also very needed by everyone. Because information technology has become the main key source and also very important for the progress of the nation. One of them is in administrative matters in ticket sales at a place of business. The current condition of processing tickets in this football stadium is still manual. Therefore, we can take advantage of the technological touch in the form of administration at the ticket booths into the football stadium and can store the data of visitors who come. The method used in this study is the waterfall model because it is a structured development method and in this final report can be done systematically and directed. The desk-top soccer ticket application program was created using Microsoft Visual Studio 2010 with VB NET as an application programming language and MySQL as a database used to store and process data. From the test results, the application made can work optimally without experiencing problems.
\end{abstract}

Keywords: Application, Ticket, Visual Studio, MySQL 


\section{PENDAHULUAN}

Dalam era globalisasi teknologi informasi merupakan hal yang penting serta dibutuhkan oleh setiap orang. Karena teknologi informasi telah menjadi sumber kunci aktifitas kehidupan masyarakat dan sangat berperan penting bagi kemajuan bangsa. Sehingga pada era ini, sebuah program pengolahan data menjadi suatu bagian yang tidak dapat terpisahkan dalam setiap aktifitas kerja.

Salah satu penerapannya berupa sistem administrasi dalam pemesanan tiket pertandingan sepak bola di sebuah tempat usaha. Selama ini proses transaksi penjualan tiket sepak bola kebanyakan masih bersifat manual sehingga kurang memperhatikan data statistik calon penonton sepak bola.

Berdasarkan hal tersebut, maka dilakukan upaya implementasi teknologi dalam bentuk aplikasi untuk administrasi pada loket pemesanan tiket masuk ke stadion sepak bola yang dapat menyimpan data para pengunjung yang datang.

Menurut Pressman (Pressman, 2010) perangkat lunak atau sering disebut software adalah sebuah instruksi yang apabila dijalankan menghasilkan fungsi dan hasil yang diinginkan. Perangkat lunak juga berarti struktur data yang dapat memanipulasi informasi. Deskripsi informasi dari ke dua poin ini menjelaskan operasi dan penggunaan dari perangkat lunak.

Perangkat lunak lebih mengacu kepada logical daripada physical system element. Oleh karena itu, perangkat lunak mempunyai karakteristik yang membedakan dengan perangkat keras yaitu :

1. Perangkat lunak dapat dikembangkan atau direkayasa bukan diciptakan.

2. Perangkat lunak tidak akan habis atau hilang.

3. Meskipun industri bergerak ke arah komponen berbasis konstruksi tetapi sebagian besar perangkat lunak tetap dibangun atau dikembangkan.

Program Aplikasi Tiket Sepak Bola Berbasis Dekstop dibuat menggunakan Visual Studio 2010 dengan bahasa pemrograman VB NET serta menggunakan database MySQL (Ramady, Suherman, \& Ramadhanti, 2019).

\section{METODE PENELITIAN}

Untuk memperoleh data serta informasi yang dapat mendukung penelitian ini, maka dilakukan studi literature berupa kajian terhadap makalah, browsing internet, dan 
korespondensi. Proses perancangan aplikasi dimulai dengan pencarian bahan yang akan dijadikan topik dalam penelitian yaitu aplikasi tiket sepak bola.

Penelitian dimulai dari menyimpan dan membuat aplikasi sampai laporan yang di susun sesuai dengan tema. Dalam penelitian ini digunakan model waterfall. Model ini dipilih karena merupakan metode pengembangan yang terstruktur dan dalam laporan akhir ini dapat dilakukan secara sistematis dan terarah. Berikut adalah gambaran mengenai langkah-langkah yang akan dilakukan:

Menurut (Kadir, 2003) model waterfall mempunyai langkah -langkah sebagai berikut seperti terlihat pada gambar berikut :

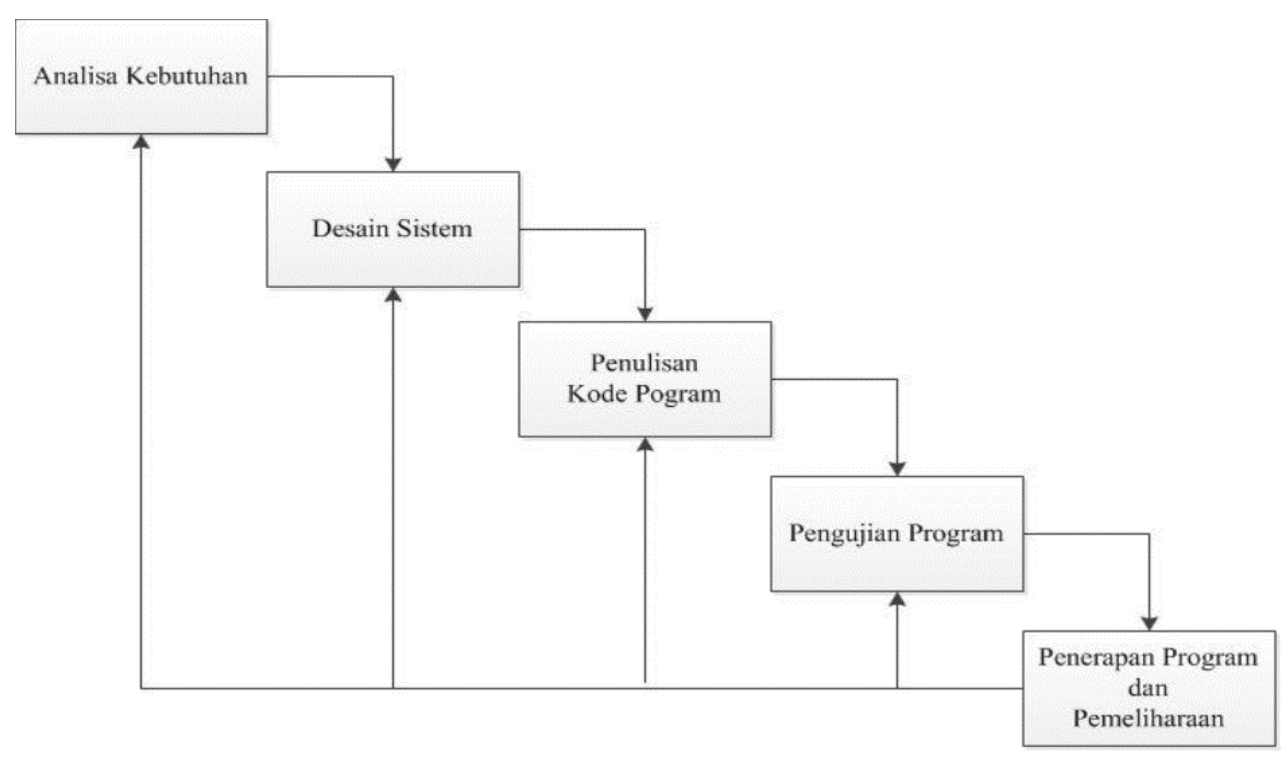

Gambar 1: Model Waterfall

Berikut adalah penjelasan dari tahap-tahap yang dilakukan di dalam model tersebut:

A. Analisa Kebutuhan

Langkah ini merupakan analisa terhadap kebutuhan sistem. Pengumpulan data dilakukan melalui wawancara dan studi literatur. Sistem analis akan menggali informasi sebanyak-banyaknya dari pemakai sehingga akan tercipta sebuah sistem komputer yang melakukan tugas-tugas yang diinginkan oleh pemakai tersebut. Tahapan ini akan menghasilkan dokumen pemakai recruitment atau dikatakan sebagai data yang berhubungan dengan keinginan pemakai dalam pembuatan sistem. Dokumen ini lah yang akan menjadi acuan sistem analis untuk menerjemahkan ke dalam bahasa pemrograman (Haryawan, 2013). 


\section{B. Desain Sistem}

Tahapan dimana dilakukan penuangan pikiran dan perancangan sistem terhadap solusi dari permasalahan yang ada dengan menggunakan perangkat pemodelan sistem seperti diagram alir data (data flow diagram) (Zhao, Si, Ni, \& Qi, 2009).

\section{Penulisan Kode Program}

Penulisan kode program atau coding merupakan penerjemahan design dalam bahasa yang dikenali oleh computer (Maseleno, 2003). Dilakukan oleh programmer yang akan menerjemahkan transaksi yang diminta oleh pemakai. Tahapan ini lah yang merupakan tahapan secara nyata dalam mengerjakan suatu sistem. Dalam artian penggunaan komputer akan dimaksimalkan dalam tahapan ini. Setelah pengkodean selesai maka akan dilakukan testing terhadap sistem yang telah dibuat tadi. Tujuan testing adalah menemukan kesalahan-kesalahan terhadap sistem tersebut dan kemudian diperbaiki.

\section{Pengujian Program}

Tahapan akhir dimana sistem yang baru diuji kemampuan dan keefektifannya sehingga didapatkan kekurangan dan kelemahan sistem yang kemudian dilakukan pengkajian ulang dan perbaikan terhadap aplikasi menjadi lebih baik dan sempurna.

\section{E. Penerapan Program dan Pemeliharaan}

Sistem yang sudah disampaikan kepada pelanggan pasti akan mengalami perubahan. Perubahan tersebut karena mengalami kesalahan karena system harus menyesuaikan dengan lingkungan baru, atau karena pelanggan membutuhkan perkembangan fungsional sehingga diperlukan pemeliharaan. Setelah menggambar dan menjelaskan langkah-langkah dalam penelitian ini, maka selanjutnya adalah mendetailkan langkah analisis dan perancangan system. 


\subsection{Perancangan Aplikasi}

\subsubsection{Pembuatan DFD}

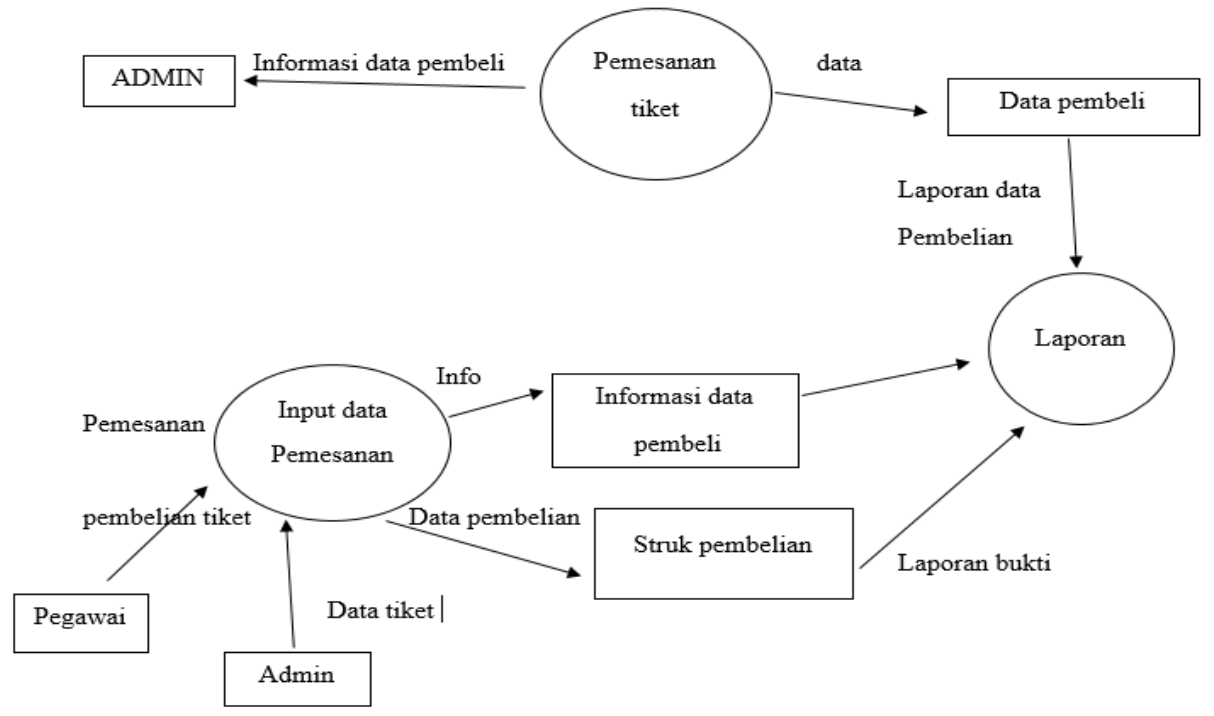

Gambar 2: Pola diagram DFD

\subsubsection{Pembuatan Flowchart}

Di bawah ini adalah tampilan gambar dari flowchart

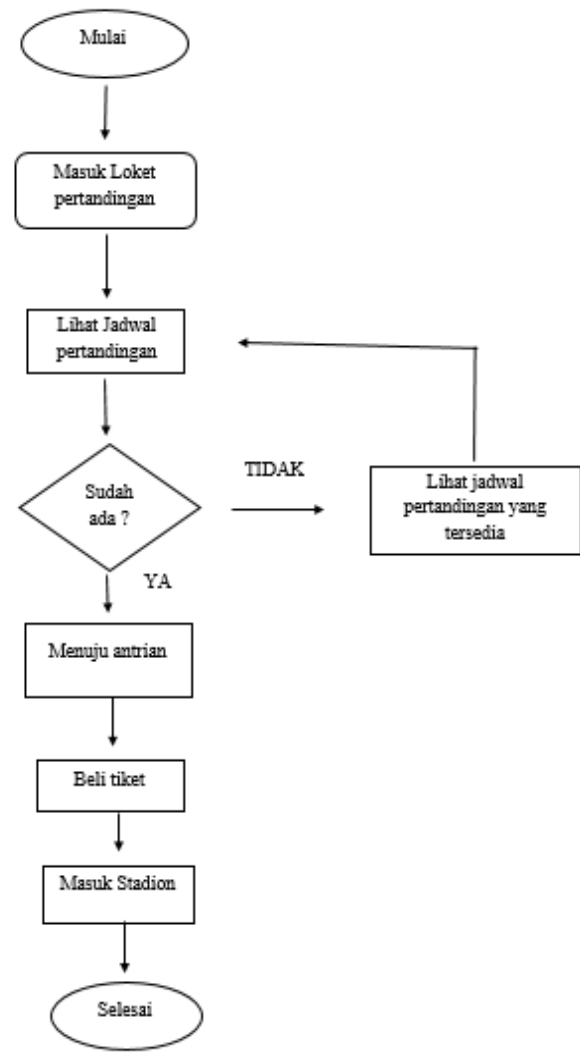

Gambar 3: Flowchart sistem 


\subsection{Tahap Perencanaan}

Proses perencanaan dilakukan setelah memperoleh judul penelitian. Pada tahapan ini dilakukan upaya berupa studi literature serta korespondensi terhadap beberapa responden sebagai bahan acuan dalam mengawali penelitian (Sinambela \& MM, 2014).

\subsubsection{Basis Data}

Adalah kumpulan informasi yang disimpan di dalam komputer secara sistematik sehingga dapat diperiksa menggunakan suatu program komputer untuk memperoleh informasi dari basis data tersebut. Sistem basis data dipelajari dalam ilmu informasi. Dan memiliki beberapa komponen dan fungsi. Berikut ini adalah tabel-tabel di dalam database oleh penulis.

Keterangan $=>$ Nama : Tabel akun

Primary key : No

Fungsi : Menyimpan data admin

Tabel 1. Akun

\begin{tabular}{|c|c|c|}
\hline FIELD & TYPE & SIZE \\
\hline No & Varchar & 100 \\
\hline Nama_pengguna & Varchar & 100 \\
\hline Pass_pengguna & Varchar & 100 \\
\hline Level_pengguna & Varchar & 100 \\
\hline
\end{tabular}

Keterangan $=>$ Nama : jadwal_pertandingan

Primary key : no_pertandingan

Fungsi : Menyimpan data pembeli

Tabel 2. Input

\begin{tabular}{|c|c|c|}
\hline FIELD & TYPE & SIZE \\
\hline No_pertandingan & Varchar & 100 \\
\hline Tim_a & Varchar & 100 \\
\hline Tim_b & Varchar & 100 \\
\hline Tempat & Varchar & 100 \\
\hline Tanggal & Varchar & 100 \\
\hline Jam & Varchar & 100 \\
\hline Harga & Int & 100 \\
\hline qty & Int & 100 \\
\hline
\end{tabular}




\subsubsection{Desain Input-Output}

Desain input-output merupakan sebuah rancangan berupa form untuk memasukkan data dan laporan sebagai informasi yang dihasilkan dari pengolahan data. Desain input-output juga merupakan acuan pembuat aplikasi dalam merancang dan membangun sistem.

\section{A. Desain Input}

Desain input merupakan perancangan desain masukan dari pengguna kepada sebuah sistem yang kemudian akan disesuaikan dengan hak akses yang sudah ditentukan sebelumnya, sehingga data yang diakses bisa dikontrol dengan baik.

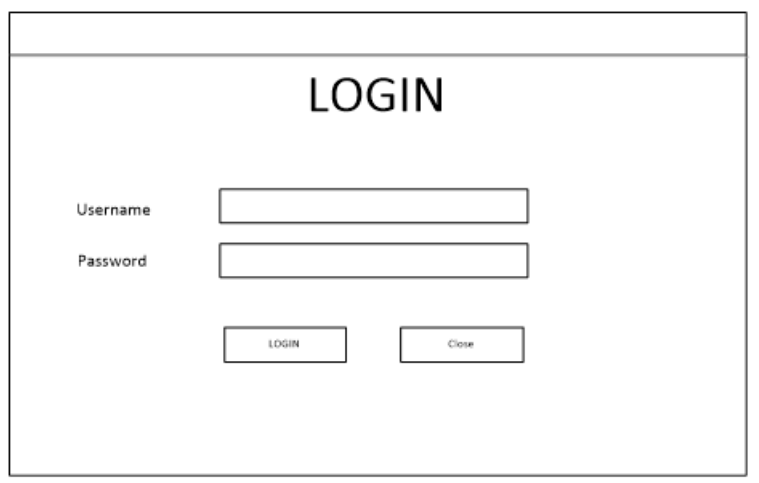

Gambar 4: Desain login form

Desain Login disini berfungsi sebagai pengaksesan melalui Aplikasi desktop dengan memasukkan username dan password yang sudah ditentukan sebelumnya guna mendapatkan hak akses.

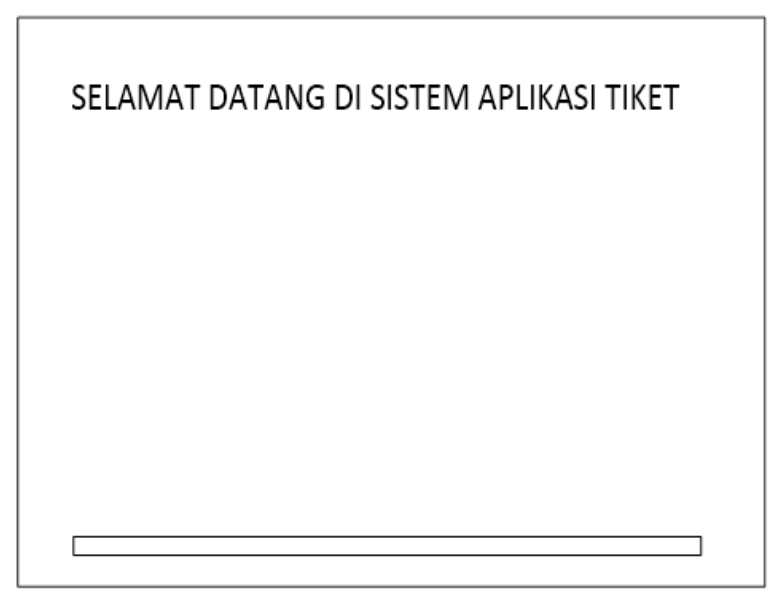

Gambar 5: Desain splashcreen

Desain splash screen ini sebelum menuju menu utama maka melewati form splash terlebih dahulu sebagai jeda menuju menu utama. 


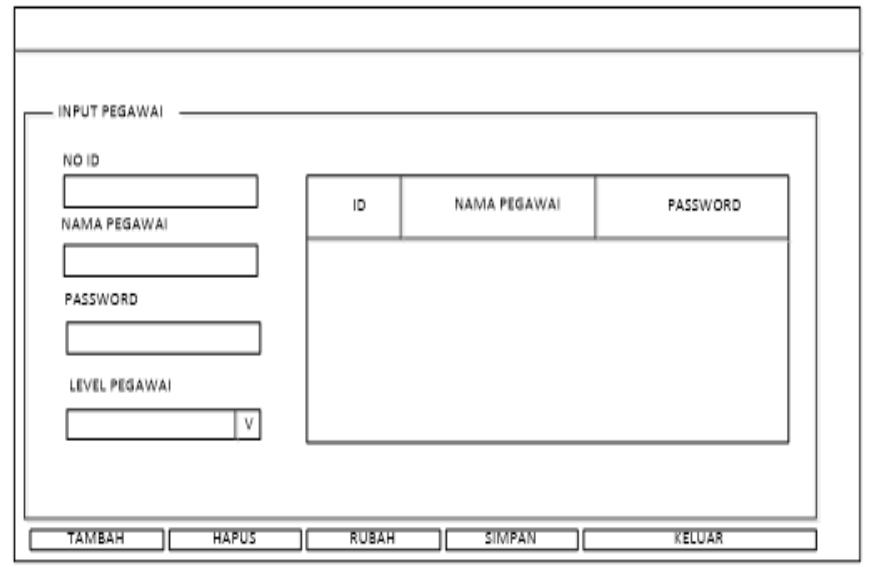

Gambar 6: Desain input pegawai

Desain input pegawai ini berfungsi sebagai untuk menampilkan data pegawai yang telah diinputkan pada aplikasi tersebut. Pada desain input pegawai selain untuk input pegawai juga dapat merubah atau menghapus data pegawai. Menu ini dapat dilakukan oleh admin.

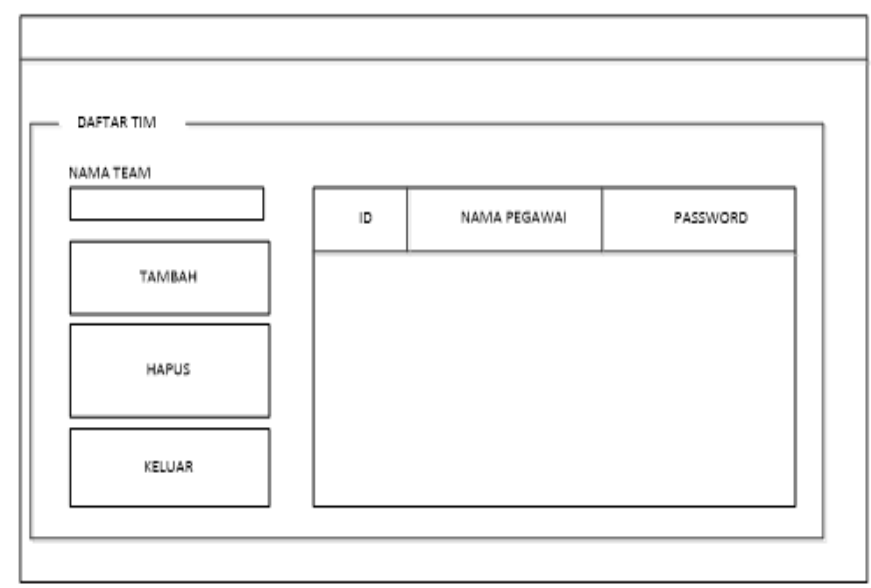

Gambar 7: Desain input team

Desain input tim ini berfungsi sebagai untuk menampilkan data tim sepak bola yang telah diinputkan pada aplikasi tersebut. Pada desain input tim selain untuk input tim juga dapat menghapus data tim. Menu ini dapat dilakukan oleh admin. 


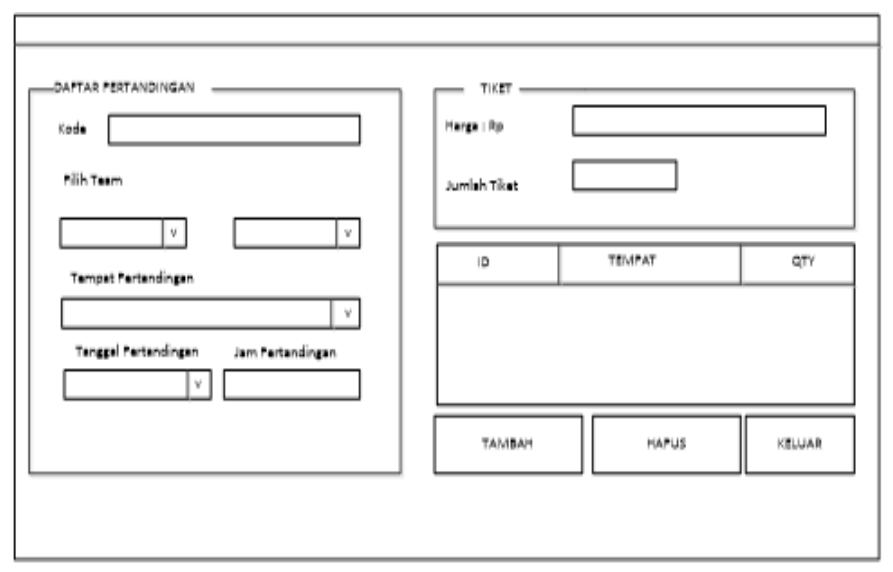

Gambar 8: Desain input jadwal

Desain input jadwal ini berfungsi sebagai untuk menampilkan data jadwal pertandingan yang telah diinputkan pada aplikasi tersebut. Pada desain input jadwal untuk mengatur jalannya pertandingan sepak bola. Menu ini dapat dilakukan oleh admin.

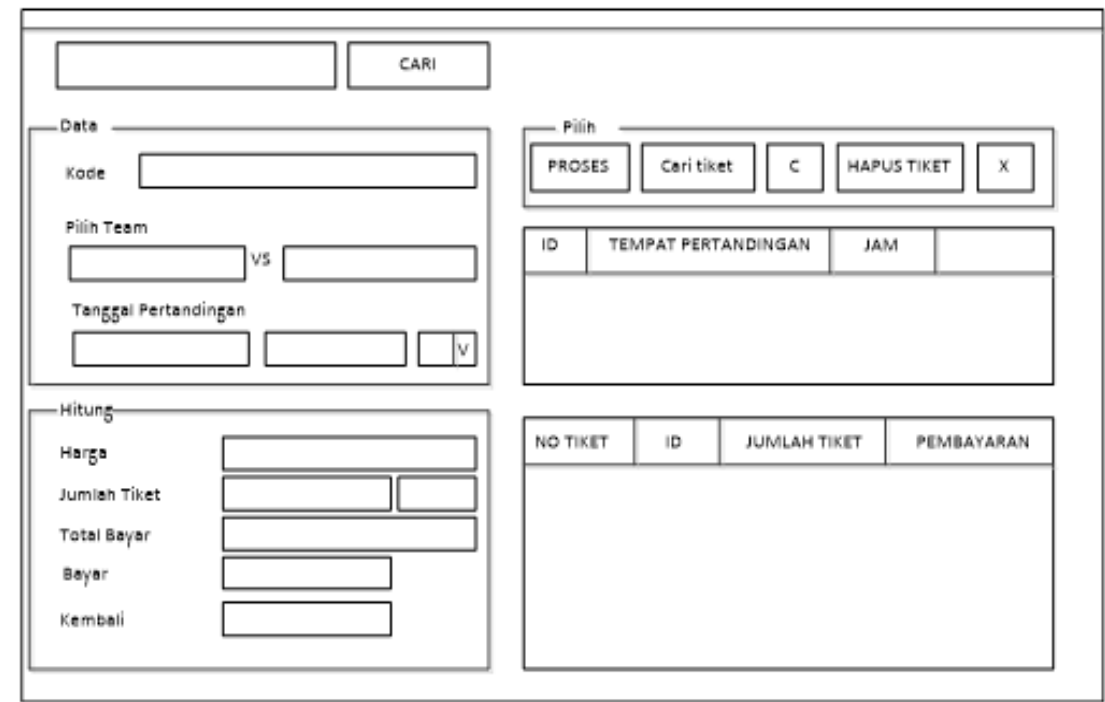

Gambar 9: Desain cetak form

Desain menu cetak tiket ini berfungsi untuk mencetak tiket pertandingan yang telah diinputkan pada aplikasi tersebut. Menu ini dapat dilakukan oleh admin.

\section{HASIL DAN PEMBAHASAN}

Implementasi sistem adalah tahap pengujian kelayakan di sistem yang dibuat sehingga aplikasi yang dibuat tidak menyimpang dari perancangan sistemnya. Desain Program Aplikasi Tiket Sepak Bola Berbasis Dekstop dibuat dengan menggunakan Microsoft Visual Studio 2010 dengan VB NET sebagai bahasa 
pemrograman aplikasi. MySQL sebagai database digunakan untuk menyimpan dan mengolah data yang akan dibutuhkan oleh Program Aplikasi Tiket Sepak Bola Berbasis Visual Basic.

\subsection{Pengujian}

Pada tahap ini, dilakukan pengujian untuk mengetahui pencapaian dari perancangan dan implementasi yang sudah dilakukan.

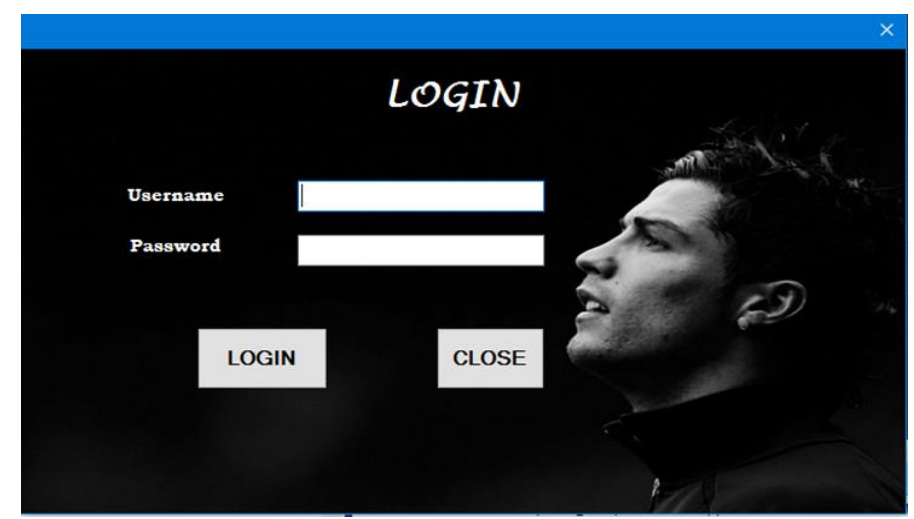

Gambar 10: Tampilan login

Ketika program dimulai , maka muncul tampilan Login, kemudian tampilan login sudah terbuka muncul lah atau terbuka lah tampilan splash screen

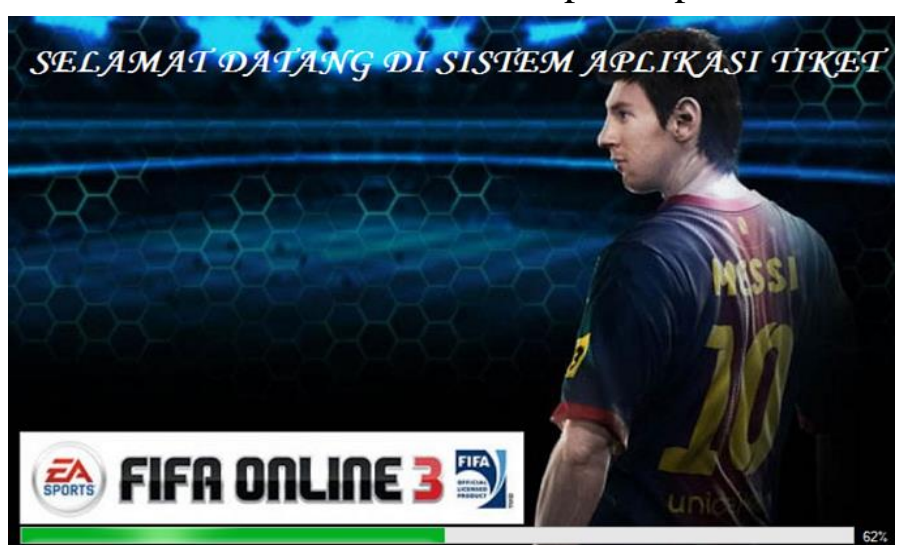

Gambar 11: Tampilan splashcreen

Setelah tampilan login sudah terbuka muncul tampilan splash screen, dan proggres bar yang ada pada splash screen mulai bergerak hingga akhir yang interval yang telah di tentukan, kemudian tampilan splash screen tertutup otomatis dan terbuka lah tampilan menu utama 


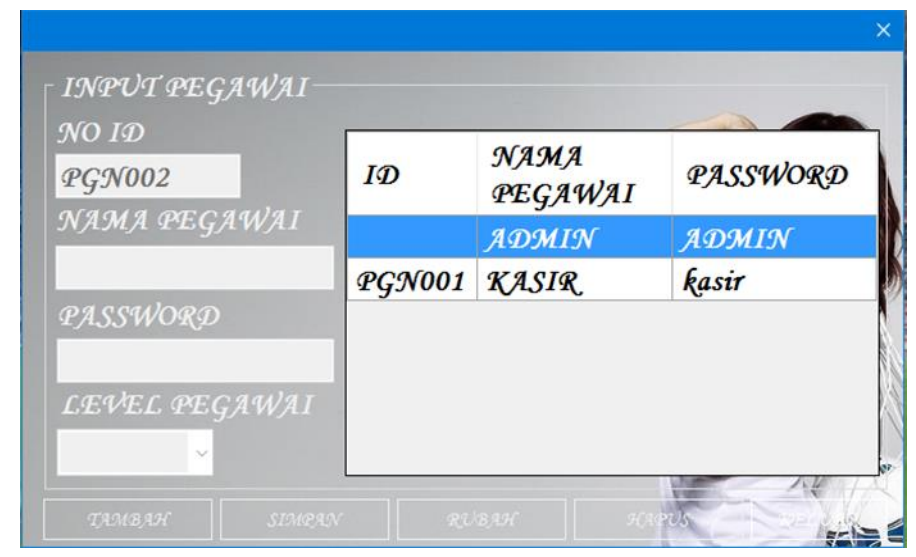

Gambar 12: Tampilan input pegawai

Setelah tampilan menu utama terbuka pilih data pegawai, di label input pegawai bisa dibuka seperti gambar diatas, dalam from input data pegawai dapat menyimpan data tambah, simpan, rubah,hapus dan yang terakhir keluar. Di daftar team ada pilihan input data yang kita akan menginputkan data team pertandingan

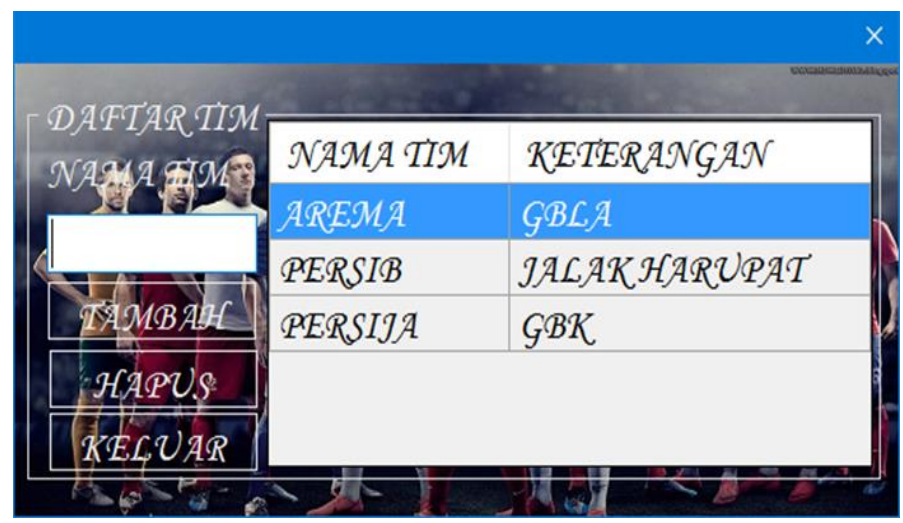

Gambar 13: Tampilan input team

Setelah Input Pegawai tertutup, terbuka lah tampilan input team seperti gambar di atas, dalam from input team dapat menyimpan data tambah,hapus, dan keluar.

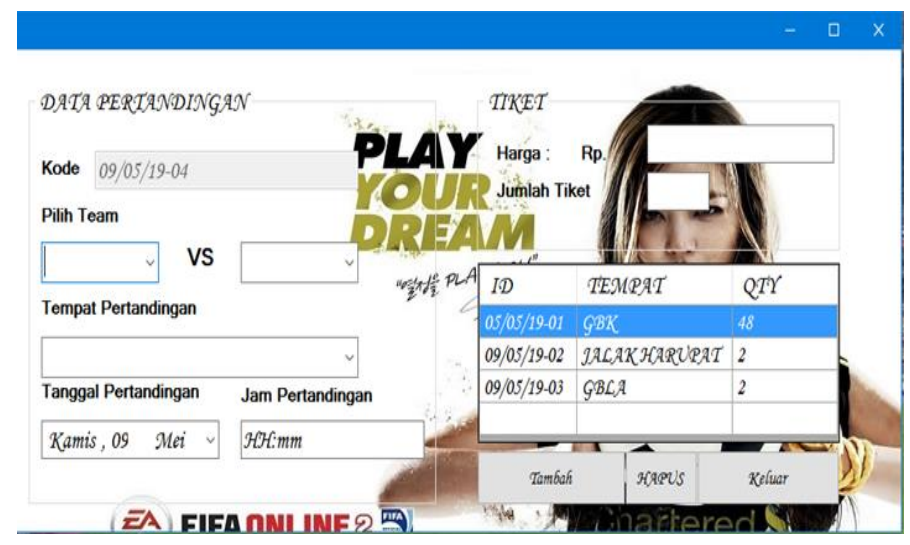

Gambar 14: Tampilan data pertandingan 
Sudah menginput data team, pilih di menu utama tampilan input jadwal di label input jadwal bisa di buka seperti gambar di atas, dalam from input ini dapat menyimpan data jumlah tiket, tambah, hapus dan yang terakhir keluar.

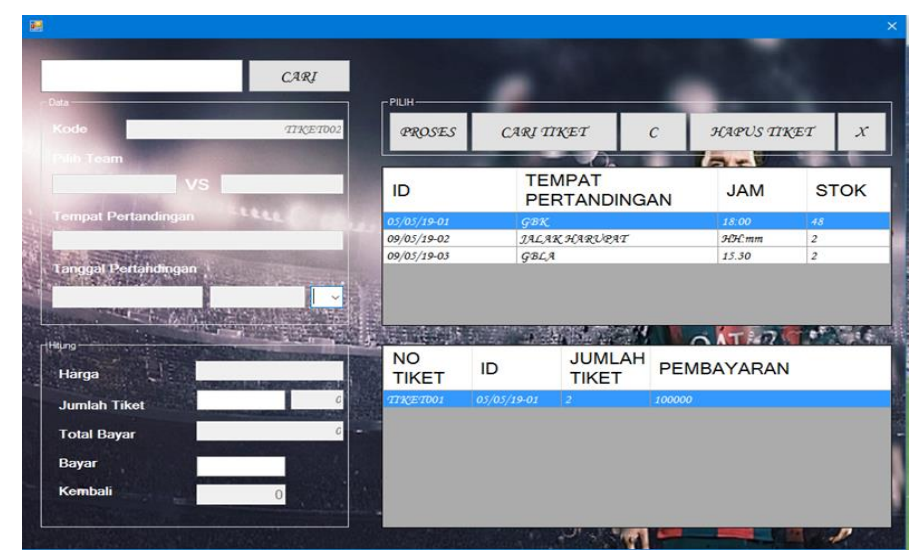

Gambar 15: Tampilan form cetak

Pada tampilan input cetak tiket hanya bisa di akses satu persatu, terdapat tombol proses, cari tiket, cetak, hapus tiket, dan keluar, setelah semua selesai muncul lah tampilan cetak tiket.

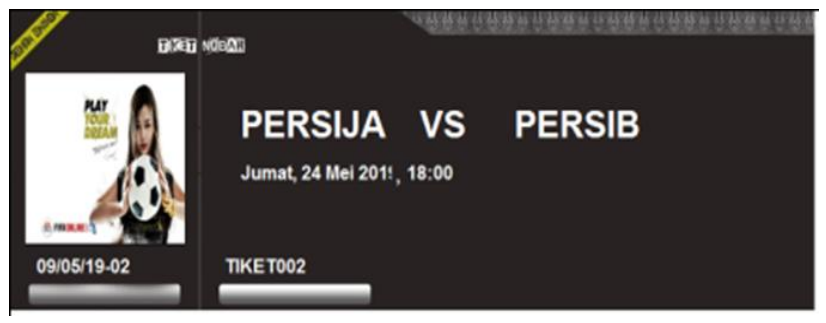

Gambar 16: Hasil cetak tiket pertandingan

\section{SIMPULAN}

Dari hasil perancangan serta pengujian terhadap program tiket sepak bola ini, maka dapat diambil beberapa kesimpulan berupa :

1. Dengan menggunakan aplikasi ini maka akan memudahkan pemilik usaha dalam memonitoring setiap transaksi penjualan tiket.

2. Dengan menggunakan aplikasi ini para calon pembeli tiket mendapatkan kemudahan dalam pemesanan maupun informasi mengenai ketersediaan tiket.

3. Program yang dibuat dapat memiliki nilai lebih bila kedepannya dapat diakses secara online melalui mobile. 


\section{DAFTAR PUSTAKA}

Haryawan, C. (2013). Sistem informasi manajemen.

Kadir, A. (2003). Dasar pemrograman web dinamis menggunakan PHP. Andi.

Maseleno, A. (2003). Kamus Istilah Komputer dan Informatika. Edisi Ketiga, Penerbit Gaya Media, Jakarta.

Pressman, R. S. (2010). Software engineering, sevent edition. America, Mc-Graw Hill.

Ramady, G. D., Suherman, A., \& Ramadhanti, T. S. (2019). Perancangan Aplikasi

Digital Menu Kafe Coffe 86 Berbasis Desktop Menggunakan Visual Studio 2010. Prosiding Seminar Nasional Teknoka, 4, I63-I69.

Sinambela, L. P., \& MM, M. P. (2014). e'todologi Penelitian, Kuantitatif.

Zhao, Y., Si, H., Ni, Y., \& Qi, H. (2009). A service-oriented analysis and design approach based on data flow diagram. 2009 International Conference on Computational Intelligence and Software Engineering, 1-5. IEEE. 